Canada is, however, running India very close, and the staff of the Ottawa Experimental Farm is actively engaged in studying wheat production, in raising new varieties suited to the different regions, and in devising new methods of management or cultivation likely to increase the yield. It is satisfactory, also, to find that Australia has considerably increased ber shipments of wheat and sent more than in any previous year; the yields for some of the States would seem to indicate even further possibilities of increase.

\section{GEORGE MATTHEY, F.R.S.}

THE death of Mr. George Matthey, F.R.S., on February 14 , in his eighty-eighth year, removes one who whilst actively engaged in commercial work was at the same time keenly interested in scientific progress.

During the early years of his life Mr. Matthey's time was devoted not only to developing and extending the business in Hatton Garden, but alsu to a most careful study of platinum and its associated metals, and he devised methods by which these metals could be separated quantitatively from each other on a large scale. These methods were described by him in the Proceedings of the Royal Society for 1879 (vol. xxviii,, p. 463).

In 1870 an international metric commission met in Paris. Its object was the construction and verification of a new and uniform series of standards, and upon it served such masters of metallurgical and chemical arts as Deville, Debray, and Stas. Certain members of the commission undertook the work of purifying the platinum and iridium of which the new standards were to be composed.

After much labour had been expended, the alloy consisting of platinum with ro per cent. of iridium was produced, but on analysis it was found to be impure. At this stage Mr. Matthey was invited by the French Minister of War, at the instigation of several important official bodies, to prepare the necessary quantity of alloy. He at once undertook the work of making the large quantities of platinum and iridium in the highest state of purity, and finally cast the ingots of the alloy in Paris. These ingots were submitted to the most rigid analysis, and proved to be exactly of the composition required.

Mr. Matthey was then invited to construct the bars of the somewhat peculiar cross-section which had been already decided upon. The writer well remembers Mr. Matthey telling him that his friends besought him to have nothing to do with the construction of the bars; he was not, however, a man to be daunted by a difficu ty of this sort, and he went into the City and bought a second-hand lathe, and set one of his skilled workmen to produce the bars of the desired crosssection. The bars fulfilled all the conditions that were laid down. Copies of them were supplied to all the larger countries of the world, and they now constitute the standards upon which the metric system rests. Mr. Matthey was appointed a member of the Legion of Honour, and in 1879 he was elected a fellow of the Royal Society.

Notwithstanding the absorbing character of business affairs and inroads on his leisure necessitated by his deep interest in scientific progress, Mr. Matthey found time to interest himself in educational matters; he played a very active part in the foundation of the City and Guilds Colleges for the advancement of technical education at Finsbury and South Kensington, and served for many years on the executive governing body of those institutions. His wide knowledge of affairs and his keen judgment of men played no small part in determining the signal success of these two colleges from their very inception. The very complete scheme of technical education with which London is provided is in a large measure due to the enthusiastic efforts of $\mathrm{Mr}$. Matthey in association with two other prominent members of the Goldsmiths Company, Sir Walter S. Prideaux and the late Sir Frederick Abel.

Mr. Matthey for a very prolonged period served as a warden of the Goldsmiths' Company, where his counsel and advice were of the greatest assistance on questions relating to assaying and the precious metals. Almost all who work at scientific research are under a deep debt of gratitude to Mr. Matthey and his firm for unvarying kindness in helping them out of many difficulties by placing the resources of their works so freely at their disposal.

Those who had the privilege of counting $\mathrm{Mr}$. Matthey as a friend realise that they have lost a truly delightful companion, remarkable not only for the wide breadth of his sympathies, but also for his genial temperament and abhorrence of all that savoured of sham.

C. T. H.

\section{NOTES.}

Mr. David Hooper, curtitor of the Industrial Section, Indian Museum, Calcutta, has been appointed economic botanist to the Botanical Survey of India.

The Rev. A. H. Cooke, author of an important work on molluscs ("Cambridge Natural History Series"), has succeeded Mr. R. Bullen Newton in the presidency of the Malacological Society of London.

THE Toronto correspondent of The Times states that the Dominion Government will grant Mr. Stefansson the sum of ${ }_{15}, 000 l$. towards his expedition into unexplored territory north of the Canadian mainland. Mr. Stefansson will take with him Canadian students with scientific knowledge, and the expedition will be directly under the Canadian Geological Survey. $\mathrm{He}$ expects to be absent three winters and four summers.

DR. W. J. G. LAND, assistant professor of botany at Chicago University, has recently spent four months in investigations in Australia and the Samoan Islands, Two of these months were occupied in the collection and study of plants in the island of Tutuila, where the remarkable growth and variety of the ferns attracted special attention. Dr. Land also made observations in and around the crater of Kilauea in the Hawaitian Islands. No. 2260 , VOL. 90] 